\title{
Inhibition of histone deacetylases prevents cytokine-induced toxicity in beta cells
}

\author{
L. Larsen • M. Tonnesen • S. G. Ronn • J. Størling • \\ S. Jørgensen • P. Mascagni - C. A. Dinarello • \\ N. Billestrup • T. Mandrup-Poulsen
}

Received: 8 June 2006 / Accepted: 30 October 2006 / Published online: 31 January 2007

(C) Springer-Verlag 2007

\begin{abstract}
Aims/hypothesis The immune-mediated elimination of pancreatic beta cells in type 1 diabetes involves release of cytotoxic cytokines such as IL- $1 \beta$ and IFN $\gamma$, which induce beta cell death in vitro by mechanisms that are both dependent and independent of nitric oxide (NO). Nuclear factor kappa B (NFKB) is a critical signalling molecule in inflammation and is required for expression of the gene encoding inducible NO synthase (iNOS) and of proapoptotic genes. NFKB has recently been shown to associate with chromatin-modifying enzymes histone acetyltransferases and histone deacetylases (HDAC), and positive effects of HDAC inhibition have been obtained in several inflammatory diseases. Thus, the aim of this study was to investigate whether HDAC inhibition protects beta cells against cytokine-induced toxicity.

Materials and methods The beta cell line, INS-1, or intact rat islets were precultured with HDAC inhibitors suberoylanilide hydroxamic acid or trichostatin $\mathrm{A}$ in the absence
\end{abstract}

L. Larsen $\cdot$ M. Tonnesen $\cdot$ S. G. Ronn $\cdot$ J. Størling $\cdot$ S. Jørgensen $•$

N. Billestrup $\cdot$ T. Mandrup-Poulsen $(\bowtie)$

Steno Diabetes Center,

2 Niels Steensens Vej,

2820 Gentofte, Denmark

e-mail: tmpo@steno.dk

P. Mascagni

Italfarmaco,

Milan, Italy

C. A. Dinarello

Department of Medicine, Division of Infectious Diseases,

University of Colorado Health Sciences Center,

Denver, CO, USA

T. Mandrup-Poulsen

Department of Molecular Medicine, Karolinska Institute,

Stockholm, Sweden or presence of IL-1 $\beta$ and IFN $\gamma$. Effects on insulin secretion and NO formation were measured by ELISA and Griess reagent, respectively. iNOS levels and NFKB activity were measured by immunoblotting and by immunoblotting combined with electrophoretic mobility shift assay, respectively. Viability was analysed by 3-(4,5-dimethyldiazol-2yl)-2,5-diphenyl-tetrazolium bromide and apoptosis by terminal deoxynucleotidyl transferase mediated dUTP nick end labeling (TUNEL) assay and histone-DNA complex ELISA.

Results HDAC inhibition reduced cytokine-mediated decrease in insulin secretion and increase in iNOS levels, NO formation and apoptosis. IL-1 $\beta$ induced a bi-phasic phosphorylation of inhibitor protein kappa $\mathrm{B} \alpha(\mathrm{I} \kappa \mathrm{B} \alpha)$ with the 2 nd peak being sensitive to HDAC inhibition. No effect was seen on $I \kappa B \alpha$ degradation and NFKB DNA binding. Conclusions/interpretation HDAC inhibition prevents cytokine-induced beta cell apoptosis and impaired beta cell function associated with a downregulation of NFKB transactivating activity.

Keywords Autoimmunity · Beta cells · Cell signalling · Histone deacetylases $\cdot$ IFN $\gamma \cdot$ IL- $1 \beta \cdot$ Nitric oxide · Nuclear factor kappa B $\cdot$ SAHA $\cdot$ TSA

$\begin{array}{ll}\text { Abbreviations } \\ \text { EMSA } & \text { electrophoretic mobility shift assay } \\ \text { HDAC } & \text { histone deacetylase } \\ \text { IKB } \alpha & \text { inhibitor protein kappa B alpha } \\ \text { iNOS } & \text { inducible nitric oxide synthase } \\ \text { MTT } & \begin{array}{l}\text { 3-(4,5-dimethyldiazol-2-yl)-2,5-diphenyl- } \\ \text { tetrazolium bromide }\end{array} \\ \text { NO } & \begin{array}{l}\text { nitric oxide } \\ \text { NF } \kappa \text { B }\end{array} \\ \text { nuclear factor kappa B } \\ \text { SAHA } & \text { suberoylanilide hydroxamic acid }\end{array}$


TUNEL terminal deoxynucleotidyl transferase mediated dUTP nick end labeling

\section{Introduction}

The double-stranded DNA helix is wrapped around core histones (H2A, H2B, H3 and H4) forming nucleosomes, which are further coiled and compacted into the higherorder chromosomal structure. It is widely accepted that this densely packed DNA structure is maintained by the enzymatic activity of the histone deacetylases (HDAC), which maintain the histones in a deacetylated state. Deacetylated histones prevent the binding of transcription factors and suppress the transcriptional machinery [1-3]. Inhibition of HDACs results in hyper-acetylation and unravelling of DNA permitting gene activation. There are, however, exceptions to this general rule [4-6].

Significant interest has emerged in the blocking of HDAC activity as a possible treatment in neoplasia. Inhibition of HDAC decreases proliferation and induces terminal differentiation or cell death in several cancers, and HDAC inhibitors have been tested in Phase I to II trials for the treatment of various malignancies [1].

In recent years, a potent anti-inflammatory effect of HDAC inhibitors at concentrations lower than those needed to suppress tumour cell growth in vitro and in vivo has been discovered [7]. This has proven to be advantageous in autoimmune diseases such as rheumatoid arthritis or systemic lupus erythematosus, where treatment with HDAC inhibitors blocks production of inflammatory mediators such as nitric oxide (NO) and cytokines in vitro and disease progression in vivo in animal models [8-10]. Although the molecular mode of action of HDAC inhibition is still debated, inhibition of the transcription factor nuclear factor $\kappa \mathrm{B}(\mathrm{NF} \mathrm{KB})$ seems to be important [1], raising the hypothesis that similar mechanisms could operate in beta cells, where the activation of $\mathrm{NF} \kappa \mathrm{B}$ and the resulting formation of $\mathrm{NO}$ is a critical event.

The NFkB family of proteins encompasses five mammalian members: p65 (RelA), RelB, c-relA, p50 and p52, and these form various homo- and heterodimers, depending on cell type and inducing stimuli [11]. Activation of the NF $k B$ pathway is initiated by stimulus-dependent phosphorylation of the inhibitor $\mathrm{\kappa B}$ protein, inhibitor protein kappa $\mathrm{B}$ alpha $(\mathrm{I} \kappa \mathrm{B} \alpha)$, which in the resting cell retains NFKB in the cytoplasm. Phosphorylation triggers ubiquitination and subsequent degradation of $\mathrm{I} \kappa \mathrm{B} \alpha$ by the $26 \mathrm{~S}$ proteasome complex and releases $\mathrm{NF} \kappa \mathrm{B}$, which can then translocate to the nucleus, bind to $\mathrm{kB}$ enhancer elements and activate gene transcription [12]. As part of a negative feed-back loop, NFKB induces production of its own negative regulator, $\mathrm{I} \kappa \mathrm{B} \alpha$, which inactivates $\mathrm{NF} \kappa \mathrm{B}$ and terminates the $\mathrm{NF} \kappa \mathrm{B}$ response by shuttling the $\mathrm{NF} \kappa \mathrm{B}-\mathrm{I} \kappa \mathrm{B} \alpha$ complex back to the cytoplasm [13].

In addition to histones, other proteins, including transcription factors such as NFkB, can be modified by acetylation/deacetylation [12, 14]. NFKB acetylation leads to increased DNA-binding, enhanced transactivation and resistance to assembly with $\mathrm{I} \kappa \mathrm{B} \alpha[12]$.

$\mathrm{NF} K \mathrm{~B}$ is a point of convergence in the signal transduction pathways activated by the proinflammatory cytokine IL- $1 \beta$ in beta cells, and plays a pivotal role in the cytokineinduced beta cell death seen in type 1 diabetes [15-17]. $\mathrm{NF} \kappa \mathrm{B}$ controls induction of several inflammatory genes, one being the gene encoding inducible NO synthase (iNOS), leading to NO formation and beta cell death [17, 18]. Blockade of the NFKB pathway has been shown to inhibit Fas-triggered apoptosis and cytokine-induced suppression of glucose-stimulated insulin secretion in human islets [16], as well as expression of the nitric oxide synthase 2 gene, NO formation and cell death by apoptosis and necrosis in primary rat islets [17].

Using both beta cell lines and primary beta cells, as well as two different HDAC inhibitors, namely trichostatin A (TSA), and suberoylanilide hydroxamic acid (SAHA), we investigated the role of acetylation/deacetylation regulation in cytokine-induced beta cell toxicity.

\section{Materials and methods}

Reagents Recombinant mouse IL- $1 \beta$ was from BD Pharmingen (Erembodegen, Belgium), whereas recombinant rat IFN $\gamma$ was obtained from R\&D Systems (Oxford, UK).

The HDAC inhibitor SAHA was synthesised by Italfarmaco (Cinisello Balsamo, Italy) [19], while TSA was purchased from Calbiochem (San Diego, CA, USA). Both inhibitors were dissolved in DMSO (vehicle) to a stock concentration of 1 and $200 \mu \mathrm{mol} / 1$, respectively.

Cells INS-1 and INS-1E cells were a kind gift from C. Wollheim, Departments of Cell Physiology and Metabolism, University Medical Center, Geneva, Switzerland [20] and were maintained in RPMI-1640 culture medium with glutamax supplemented with 10\% FCS, $100 \mathrm{U} / \mathrm{ml}$ penicillin, $100 \mu \mathrm{g} / \mathrm{ml}$ streptomycin (all from Invitrogen/Gibco, Taastrup, Denmark), and $50 \mu \mathrm{mol} / 1 \quad \beta$-mercaptoethanol (Sigma, St Louis, MO, USA). Cells were cultured under standard cell culture conditions at $37^{\circ} \mathrm{C}$ in a humidified atmosphere containing $5 \% \mathrm{CO}_{2}$. Cells were passaged weekly and precultured for 2 days prior to cytokine treatment. At the day of experiment medium was changed, and inhibitors were added to the specified conditions $30 \mathrm{~min}$ preceding cytokine exposure for various times. 
Islet isoloation and preculture Primary neonatal rat islets were isolated from 3- to 6-day-old Wistar Furth Rats (Charles River, Sulzfeldt, Germany) and precultured for 7 days as previously described [21, 22] in complete medium (RPMI 1640 with $100 \mathrm{U} / \mathrm{ml}$ penicillin and $100 \mu \mathrm{g} / \mathrm{ml}$ streptomycin) supplemented with $10 \%$ newborn calf serum (Invitrogen/Gibco).

Adult rat islets were obtained by the following procedure described by Eizirik et al. [23].

Islet culture Five hundred randomly picked islets per $1 \mathrm{ml}$ of complete medium $+0.5 \%$ human serum, or 50 islets per $100 \mu \mathrm{l}$ complete medium $+0.5 \%$ of human serum, were placed in 12-well or 96-well plates (NUNC, Roskilde, Denmark), respectively. Islets were left for $2-3 \mathrm{~h}$ before pre-exposure to HDAC inhibitors or control medium for $1 \mathrm{~h}$ and subsequently exposed to cytokines for various times.

Monolayer culture Islets for monolayer cultures were prepared as previously described [24].

$H D A C$ activity We analysed $20 \mathrm{ng}$ of nuclear protein, which had been extracted from INS-1 cells, for HDAC activity using an HDAC assay kit (No. 17-374; Upstate, Hampshire, UK) with or without SAHA or TSA in a final concentration of 1 or $200 \mathrm{nmol} / 1$, respectively.

Immunoblotting We seeded 500,000 INS-1E cells or 500 neonatal rat islets in 12-well plates (Nunc) in $1 \mathrm{ml}$ of complete medium. Inhibitors and cytokines were added to the indicated conditions for various time points ranging from $5 \mathrm{~min}$ to $6 \mathrm{~h}$ of stimulation. Cells were lysed, protein content measured by the Bradford method and lysates subjected to gel electrophoresis as previously described [25]. Antibody to $\mathrm{I} \kappa \mathrm{B} \alpha$ (sc-371) and $\beta$-tubulin (sc-5274) was obtained from Santa Cruz Biotechnology (Santa Cruz, CA, USA), anti phospho-IkB $\alpha$ (\#9246) from Cell Signaling (Beverly, MA, USA), anti iNOS (\#610332) from BD Pharmingen (San Diego, CA, USA) and anti $\beta$-actin (ab6276) from Abcam (Cambridge, UK). Immune complexes were detected by chemiluminescence using LumiGLO (Cell Signaling), and light emission captured digitally by use of the Fuji LAS3000 (Fujifilm, Tokyo, Japan).

Nuclear extracts and electrophoretic mobility shift assay INS-1E cells were cultured in $10 \mathrm{~cm}$ dishes to 80 $85 \%$ confluency. Cells were exposed to inhibitors and cytokines as indicated. Nuclear extracts were isolated and electrophoretic mobility shift assay (EMSA) carried out as described [26]. For detection of NFKB binding a doublestranded oligo was used: AGTCAGCTTCAGAGG GACTTTCCGAGAGG-3'. In supershift experiments, nucle- ar extracts were preincubated with anti-p65 antibody (sc-37; Santa Cruz) for $30 \mathrm{~min}$ at $4^{\circ} \mathrm{C}$.

Nitric oxide measurement We seeded 10,000 INS-1 cells or 50 rat islets in 96-well tissue-culture plates (Nunc) in $200 \mu \mathrm{l}$ complete medium. Following 2 days of cytokine exposure, NO was measured as accumulated nitrite in the medium by mixing equal volumes of cell culture medium and Griess reagent $(0.1 \%$ naphthylethene diamine hydrochloride; Sigma) in $\mathrm{H}_{2} \mathrm{O}$ and $1 \%$ sulphanilamide (Bie\& Berntsen, Rødovre, Denmark) in 5\% $\mathrm{H}_{3} \mathrm{PO}_{4}$ (Merck, Glostrup, Denmark) [27]. The absorbance was measured at $540 \mathrm{~nm}$ and nitrite calculated from a $\mathrm{NaNO}_{2}$ standard curve.

Insulin assay Cells were cultured and handled as described under NO measurement. Accumulated insulin in the incubation media was measured as previously [28, 29], except that the enzyme substrate used here was the $\mathrm{TMB}^{+}$ ready-to-use-substrate (Kem En Tec, Taastrup, Denmark).

For glucose-stimulated insulin release, islets were preincubated with SAHA and exposed to cytokines for 4 or $18 \mathrm{~h}$. Media was removed and islets were washed for $30 \mathrm{~min}$ in KRBH buffer (114.3 mmol/l NaCl, $4.74 \mathrm{mmol} / \mathrm{l} \mathrm{KCl}$, $1.15 \mathrm{mmol} / 1 \mathrm{KH}_{4} \mathrm{PO}, 1.18 \mathrm{mmol} / \mathrm{l} \mathrm{MgSO}_{4}, 25.0 \mathrm{mmol} / 1$ $\mathrm{NaHCO}_{3}, 10.0 \mathrm{mmol} / \mathrm{l}$ HEPES, $4.26 \mathrm{mmol} / \mathrm{l} \mathrm{NaHO}, 2.54$ $\mathrm{mmol} / \mathrm{l} \mathrm{CaCl}_{2} ; \mathrm{pH}$ 7.4) supplemented with $1.7 \mathrm{mmol} / 1$ glucose and SAHA and cytokines as previously, followed by $60 \mathrm{~min}$ in an identical buffer. Medium was then exchanged for $\mathrm{KRBH}$ containing $2 \mathrm{mg} / \mathrm{ml} \mathrm{BSA}$ and $16.7 \mathrm{mmol} / \mathrm{l}$ glucose for another $60 \mathrm{~min}$. Insulin was determined as above.

Viability assay Cells were cultured and handled as described under NO measurement. Following 2 days of cytokine exposure, the proportion of viable/metabolically active cells in control vs cytokine-containing wells was determined by 3-(4,5-dimethyldiazol-2-yl)-2,5-diphenyl-tetrazolium bromide (MTT) assay (Promega, Madison, WI, USA), measuring the conversion of an MTT tetrazolium salt to a coloured formazan product by the mitochondrial enzyme succinate dehydrogenase [30].

Terminal deoxynucleotidyl transferase mediated dUTP nick end labelling assay A detection kit (ApopTag Fluorescein Direct In Situ Apoptosis Detection Kit), no. S7160; Chemicon, Temecula, CA, USA) was used to detect the degree of cytokine-mediated DNA fragmentation in monolayer cultures or INS-1 cells. Monolayer cultures were starved for $24 \mathrm{~h}$ in medium without human growth hormone preceding exposure to inhibitor and addition of cytokines to the indicated conditions for $20 \mathrm{~h}$. Some 300,000 INS- 1 cells 
were cultured in two-well chamber slides (Nunc) in $1.5 \mathrm{ml}$ complete medium and exposed to cytokines for $24 \mathrm{~h}$ where indicated. The terminal deoxynucleotidyl transferase mediated dUTP nick end labelling (TUNEL) assay was performed according to the manual of the manufacturer (CHEMICON Europe, Chandlers Ford, Hants, UK).

Cells were subsequently stained with Dapi nuclear stain (Sigma) for 30-60 min at room temperature, washed in PBS and the slides were mounted using drops of Antifade Mounting Media (no. 002627; Dako, Carpintaria, CA, USA).

Cell death detection ELISA Fifty islets were transferred to each well of a 96-well plate containing $200 \mu \mathrm{l}$ of complete medium. Islets were cultured with or without inhibitors and cytokines for $24 \mathrm{~h}$. The degree of cytokine-induced apoptosis was determined by cell-death detection ELISA (ELISAPLUS; Roche, Basel, Switzerland) measuring the amount of DNA-histone complexes present in the cytoplasmic lysates according to manufacturer's description. To calculate the induction of apoptosis, values were normalised to the total amount of DNA determined by the PicoGreen assay (Roche). This assay is based on a sensitive fluorescent nucleic acid stain facilitating the quantification of double-stranded DNA in solution.

Statistical analyses All data are presented as mean $\pm \mathrm{SEM}$ of $n$ independent experiments. Statistical analysis was done using a paired Student's $t$ test and a $p$ value of less than 0.05 was considered significant.

\section{Results}

SAHA and TSA inhibit HDAC activity In order to validate the inhibitory effect of the HDAC inhibitors used, nuclear extracts from INS- 1 cells were prepared and the ability of $1 \mu \mathrm{mol} / 1$ of SAHA or $200 \mathrm{nmol} / 1$ of TSA to inhibit HDAC activity was tested using an HDAC assay. SAHA and TSA (by 47 and 44\%, respectively), significantly inhibited the HDAC activity in insulin secreting cells (Fig. 1).

HDAC inhibition protects against cytokine-induced decrease in beta cell function To investigate whether inhibition of HDACs protects against cytokine-induced toxicity, we first investigated the effect of SAHA and TSA on insulin secretion in INS-1 cells. As expected, exposure to a combination of IL- $1 \beta$ and IFN $\gamma$ for 2 days markedly reduced accumulated insulin secretion. This was partially prevented by pre-culturing the cells with $1 \mu \mathrm{mol} / 1$ of SAHA

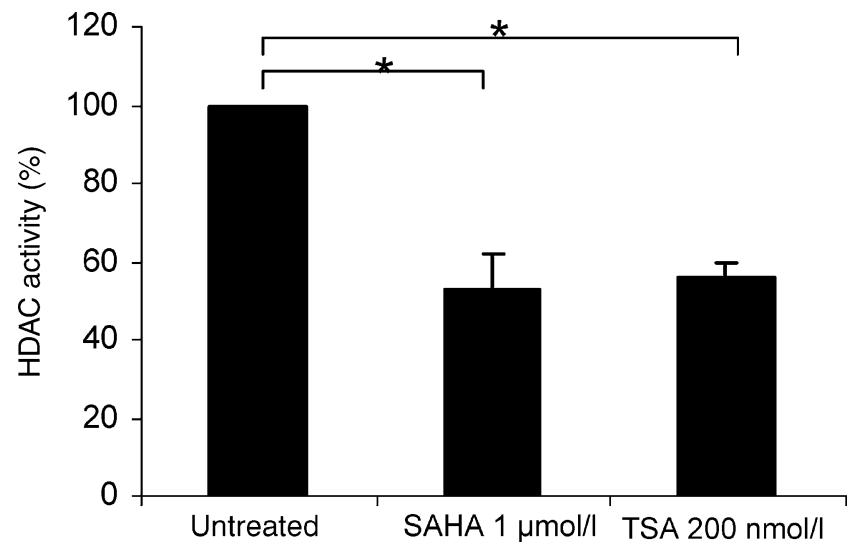

Fig. 1 Inhibitory potential of SAHA and TSA. The ability of SAHA $(1 \mu \mathrm{mol} / \mathrm{l})$ or TSA $(200 \mathrm{nmol} / \mathrm{l})$ to inhibit histone deacetylase activity was analysed by the HDAC assay using nuclear extract from INS-1 cells. Results are shown as mean \pm SEM compared with untreated extracts $(n=4) . * p<0.05$ vs untreated extracts $(t$ test $)$

or $200 \mathrm{nmol} / \mathrm{l}$ of TSA (Fig. 2a). In neonatal rat islets both inhibitors dose-dependently protected against cytokineinduced reduction in accumulated insulin secretion with complete protection seen at 1 and $200 \mathrm{nmol} / \mathrm{l}$, respectively (Fig. 2b and c). In both cell types a significant (17-36\%) reduction in insulin secretion was observed with TSA but not with SAHA alone.

To investigate the effect of HDAC inhibition on acute glucose-stimulated insulin release, we subjected primary rat islets pretreated with HDAC inhibitors and exposed to cytokines for a total of 6 or $20 \mathrm{~h}$ to low glucose $(1.7 \mathrm{mmol} / \mathrm{l})$ and a glucose challenge $(16.7 \mathrm{mmol} / \mathrm{l})$ for $1 \mathrm{~h}$. In this case we observed no effect of HDAC inhibition on cytokinemediated inhibition of glucose-stimulated insulin release (data not shown).

Using the MTT assay, we next tested whether inhibition of HDACs had a positive effect on cell viability. The MTT assay is based on the cellular reduction of formazan and tests mitochondrial function, i.e. the metabolic state of the cell. As is evident from Fig. $2 \mathrm{~d}$ and e, both SAHA and TSA dose-dependently reduced the IL-1 $\beta$ and IFN $\gamma$-mediated reduction in mitochondrial function in neonatal rat islets. Neither of the inhibitors had any effect on basal mitochondrial function. The results indicate that HDAC inhibition can protect against the detrimental effects of cytokines in both primary islets and rat beta cell line.

HDACs increase cytokine-induced beta cell apoptosis Although HDAC inhibitors increase the level of cell death in cancer cells [31, 32], opposite effects have been observed in models of autoimmune diseases, where HDAC inhibition has been shown to downregulate the pro-apoptotic pathways [33]. 
Fig. 2 Effect of HDAC inhibition on insulin secretion and metabolic activity. a INS- 1 cells were precultured with SAHA $(1 \mu \mathrm{mol} / \mathrm{l})$, TSA $(200 \mathrm{nmol} / \mathrm{l})$, or vehicle (Untreated) for $30 \mathrm{~min}$ followed by exposure to IL-1 $\beta$ $160 \mathrm{pg} / \mathrm{ml}$ and IFN $\gamma 10 \mathrm{ng} / \mathrm{ml}$ (black bars) for 2 days. Medium was collected and insulin content measured by competitive ELISA. Rat islets $(\mathbf{b}, \mathbf{c})$ were precultured with SAHA (0.2 and $1 \mu \mathrm{mol} / 1)$, TSA (25 and $200 \mathrm{nmol} / \mathrm{l}$ ), or vehicle for $60 \mathrm{~min}$ followed by IL- $1 \beta$ $150 \mathrm{pg} / \mathrm{ml}$ and IFN $\gamma 2 \mathrm{ng} / \mathrm{ml}$ treatment (black bars) for 2 days. d, e Neonatal rat islets were precultured and cytokinetreated as described (for $\mathbf{b}, \mathbf{c}$ ). Culture medium was collected and viability/mitochondrial activity investigated by the 3-(4,5dimethyldiazol-2-yl)-2,5diphenyl-tetrazolium bromide (MTT) assay. Results are shown as mean \pm SEM compared with unstimulated cells $(n=4-6)$. ${ }^{*} p<0.05,{ }^{* *} p<0.01,{ }^{* * *} p<0.001$ vs cytokine-stimulated cells; ${ }^{\#} p<0.05$ vs unstimulated cells ( $t$ test)

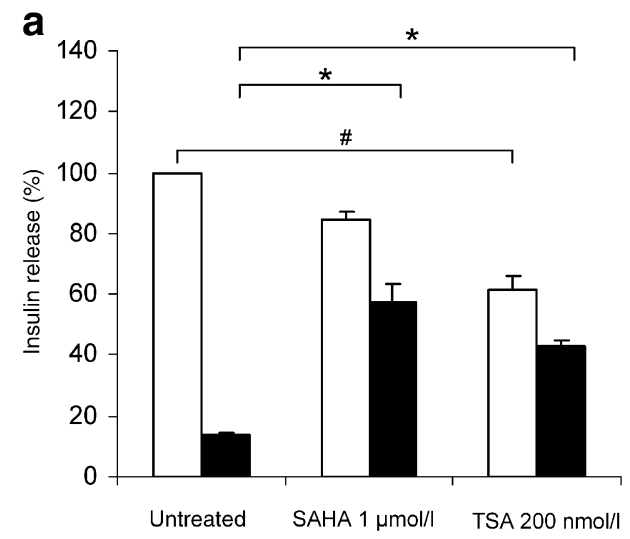

b

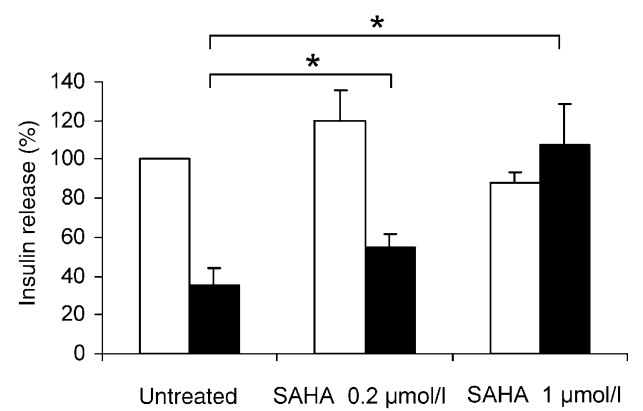

C

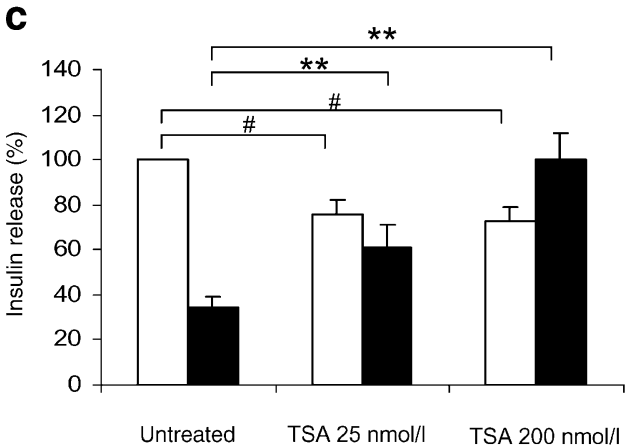

d

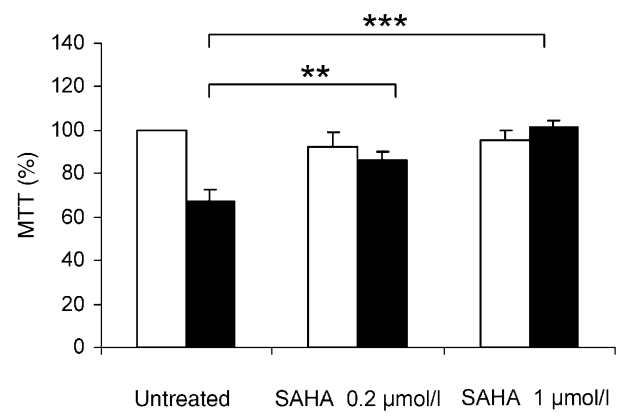

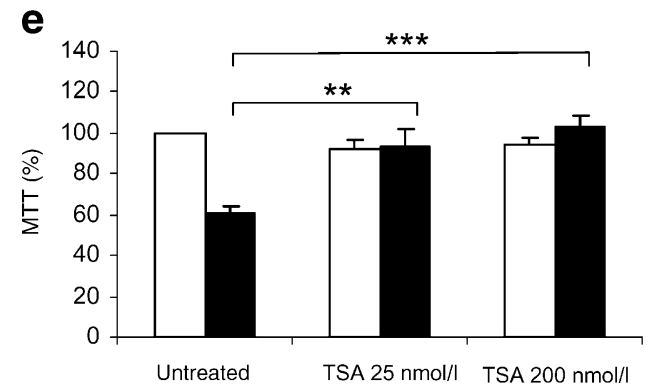

To test whether this was also the case in beta cells, we analysed beta cell apoptosis in response to cytokines using the TUNEL assay. A 40\% reduction in cytokine-stimulated apoptosis was observed in INS-1 cells precultured with either SAHA or TSA (Fig. 3a). A small but insignificant increase in basal apoptosis was detected in INS-1 cells exposed to TSA alone. In monolayer cultures isolated from neonatal rats, similar concentrations of SAHA and TSA resulted in a $60 \%$ reduction in cytokine-stimulated apoptosis with a similar toxic tendency seen using TSA alone (Fig. 3b), increasing the basal level of apoptosis from 15 to $34 \%$.

We also investigated the effect of HDAC inhibition on IL-1 $\beta$ and IFN $\gamma$-stimulated apoptosis in islets isolated from adult rats, using a cell death detection ELISA, in which the amount of DNA-histone complexes present in cytoplasmic lysates (i.e. apoptotic cells) is measured. Figure $3 \mathrm{c}$ and $\mathrm{d}$ shows that both SAHA and TSA fully protected against the detrimental effects of cytokine exposure in adult rat islets with no induction in basal apoptosis observed with either of the inhibitors alone.

Inhibition of HDACs affects the $N F \kappa B$-dependent production of $i N O S$ and formation of $N O \mathrm{IL}-1 \beta$ is known to induce expression of the gene encoding iNOS, an effect that is potentiated by IFN $\gamma[18,34]$. The subsequent formation of NO drives cell death by both necrosis and apoptosis, at least in rodent beta cells [35]. Thus, we next examined whether the protective effect of HDAC inhibition against cytokine-induced beta cell death was associated with a reduction in iNOS production. As shown in Fig. $4 a$ and $b$, both SAHA and TSA dose-dependently reduced iNOS protein production in INS-1 cells. Using neonatal rat islets, a complete prevention of cytokine-stimulated iNOS pro- 
Fig. 3 Effect of HDAC inhibition on cytokine-induced apoptosis. a INS-1 cells were pre-cultured with vehicle, SAHA or TSA for $30 \mathrm{~min}$. Subsequently cytokines were added for $20 \mathrm{~h}$ (black bars). Cells were permeabilised and fixed and enzymatic labelling of DNA strand breaks was performed by use of the TUNEL assay. b TUNEL assay performed on monolayer cultures from neonatal rat islets as described for INS-1 cells except that pre-culturing with inhibitors was done for $60 \mathrm{~min}$. c, d Adult rat islets were pre-cultured as described and exposed to cytokines for $24 \mathrm{~h}$. Amount of DNA-histone complexes present in the cytoplasm (i.e. apoptosis) was determined by cell death detection ELISA and correlated to total amount of DNA. Data are presented as mean \pm SEM compared with cytokinestimulated cells $(n=3-4)$. ${ }^{*} p<0.05,{ }^{* *} p<0.01$ vs cytokinestimulated cells ( $t$ test) a

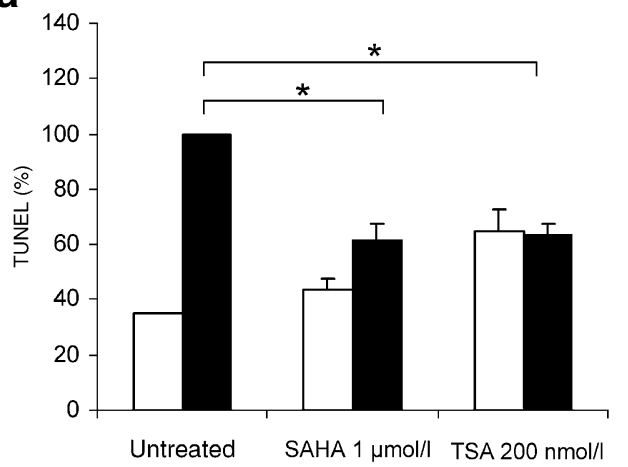

C

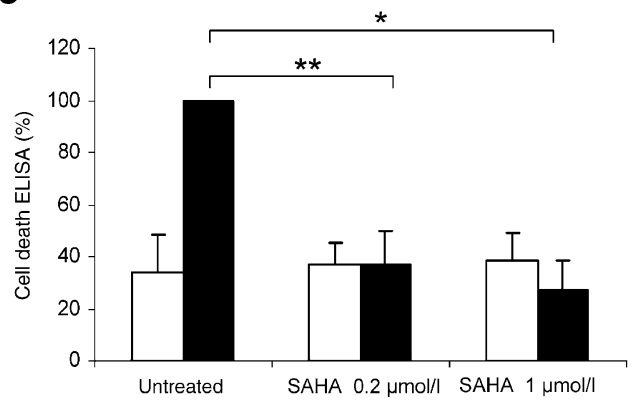

b

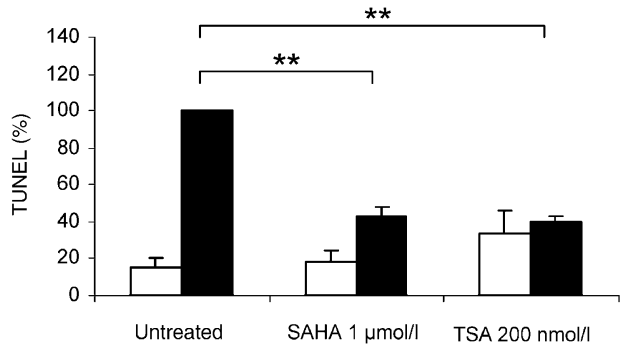

d

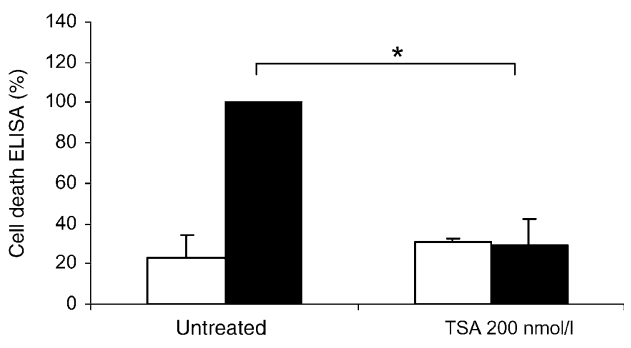

duction was obtained at 1 and $200 \mathrm{nmol} / \mathrm{l}$ of SAHA and TSA, respectively (Fig. 4c). Accordingly, SAHA, and in particular TSA significantly reduced NO formation in INS1 cells (Fig. 4d). In addition, a 44-46\% reduction in NO formation was detected using SAHA (Fig. 4e) or TSA (Fig. 4f) in neonatal rat islets.

$H D A C$ inhibitors affect the $N F \kappa B$ signalling pathway As $\mathrm{NFKB}$ is the key transcription factor responsible for cytokine-induced iNOS production, the results presented above imply that HDACs are involved in the regulation of NF $\kappa B$ transcriptional activity.

To further clarify the potential modulating effect of HDAC inhibition on NFKB activity, we next dissected the level of inhibition by analysing upstream components of the NFKB signalling cascade.

A time-response experiment revealed that IL- $1 \beta$ triggered a bi-phasic phosphorylation of the NFKB inhibitor protein, I $\mathrm{K} B \alpha$, the first peak in phosphorylation being evident within $5 \mathrm{~min}$ and the second peak after 30-60 min of cytokine exposure in INS-1 cells (Fig. 5a) and neonatal rat islets (Fig. 5b). Following phosphorylation, I $\kappa \mathrm{B} \alpha$ is ubiquitinated and degraded, as seen in the immunoblot showing total-IkB $\alpha$ after 10 to $15 \mathrm{~min}$ of IL- $1 \beta$ exposure (Fig. 5a). After $60 \mathrm{~min}$ of stimulation, total $\operatorname{I\kappa B} \alpha$ reappeared, coinciding with the second peak of phosphory- lation, which indicates that the NFKB pathway is still activated after $60 \mathrm{~min}$ of cytokine exposure. The reappearance of $I \kappa B \alpha$ is probably due to NFKB-mediated expression of its own inhibitor, as part of a negative feedback mechanism.

To investigate whether NFKB activity was influenced by HDAC inhibition at this level in the signalling cascade, a similar experiment was performed, in which INS-1 cells were precultured with SAHA or TSA before IL-1 $\beta$ exposure. From Fig. 5c it can be concluded that the second peak in phosphorylation at $60 \mathrm{~min}$ of stimulation is inhibited by SAHA or TSA. This effect is associated with a lack of re-synthesis of total $\operatorname{IkB} \alpha$ as evident from the greater level of $\operatorname{IkB} \alpha$ following 60 min of IL- $1 \beta$ stimulation alone as compared with islets co-exposed to HDAC inhibitors and IL-1 $\beta$ (Fig. 5c, lanes 4, 7 and 10). Similar effects were seen with SAHA using primary rat islets (Fig. 5d). These data support the notion that inhibition of HDACs reduces NFKB-dependent gene expression.

As $I \kappa B \alpha$ is degraded, NF $\kappa B$ translocates to the nuclear compartment and binds to DNA. To ascertain whether NFKB translocation and DNA binding were reduced by the HDAC inhibitors, nuclear extracts from INS-1E cells pre-incubated with or without the inhibitor alone or in combination with cytokines were isolated and examined by EMSA (Fig. 5e). Although IL-1 $\beta$ and IFN $\gamma$ clearly induced NFKB DNA binding after $60 \mathrm{~min}$ of 


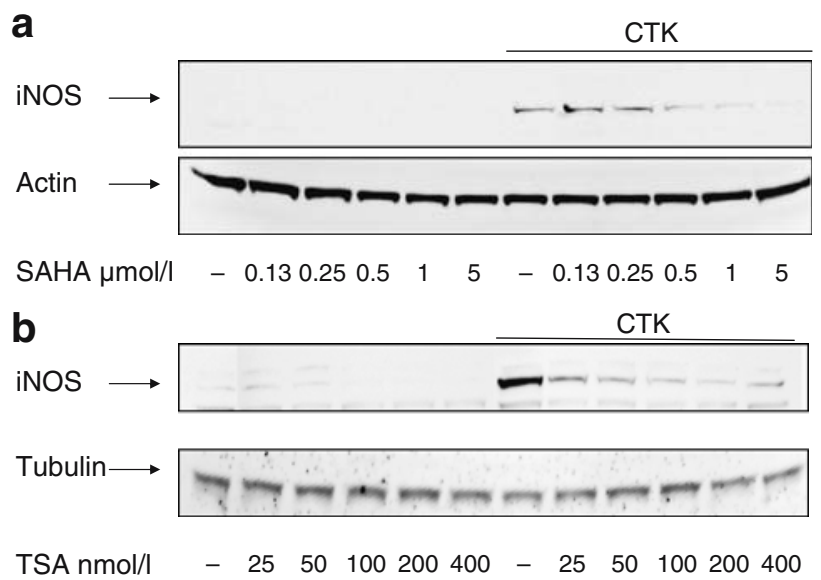

C

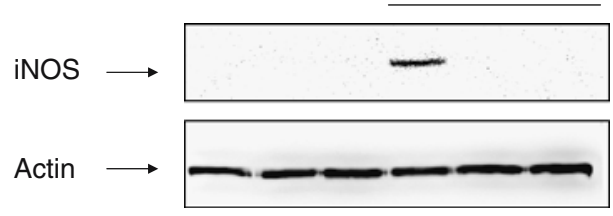

SAHA $1 \mu \mathrm{mol} / \mathrm{l}-$ TSA $200 \mathrm{nmol} / \mathrm{l}-$

d

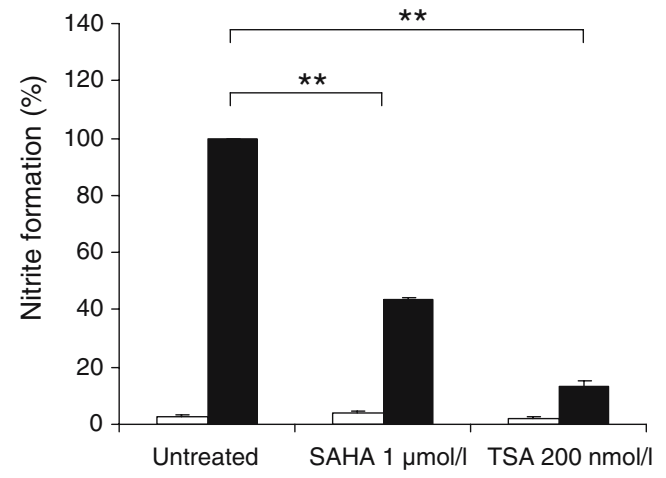

e

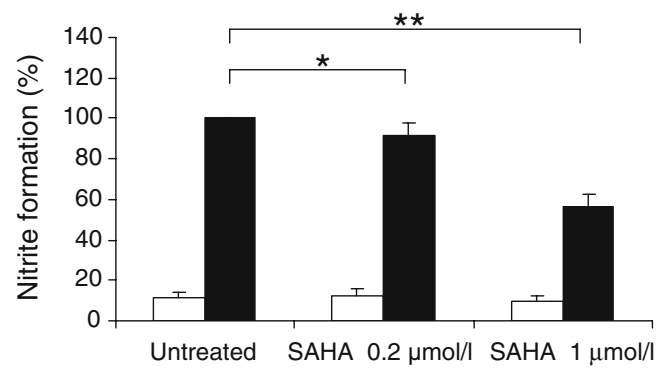

$\mathbf{f}$

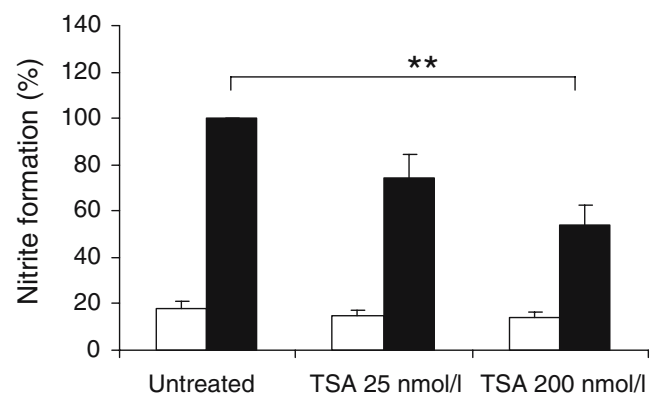

4 Fig. 4 Effect of HDAC inhibition on iNOS production and NO formation. a, b INS-1E cells were pre-cultured for $30 \mathrm{~min}$ with increasing concentrations either of SAHA (a) followed by cytokines (CTK) IL-1 $160 \mathrm{pg} / \mathrm{ml}$ and IFN $\gamma 5 \mathrm{ng} / \mathrm{ml}$ for $6 \mathrm{~h}$, or of TSA (b) followed by IL-1 $\beta 160 \mathrm{pg} / \mathrm{ml}$ (CTK) exposure for $6 \mathrm{~h}$. Lysates were subjected to immunoblotting using antibodies against iNOS or the house-keeping proteins actin or tubulin. Representative blots are shown $(n=4)$. c Neonatal rat islets were pre-cultured with SAHA $(1 \mu \mathrm{mol} / \mathrm{l})$ or TSA $(200 \mathrm{nmol} / \mathrm{l})$ for $60 \mathrm{~min}$ followed by IL-1ß $150 \mathrm{pg} / \mathrm{ml}+\mathrm{IFN} \gamma$ $(2 \mathrm{ng} / \mathrm{ml})(\mathrm{CTK})$ for $6 \mathrm{~h}$. iNOS production was analysed as above $(n=3)$. d-f INS-1 cells or neonatal rat islets were pre-cultured with vehicle or inhibitors and exposed to cytokines (black bars) for 2 days. Medium was collected and nitrite content determined by Griess reagent. Data are presented as mean \pm SEM compared with cytokine-exposed cells $(n=3-6) .{ }^{*} p<0.05,{ }^{* *} p<0.01$ vs cytokine-stimulated cells $(t$ test $)$

stimulation, no difference in band intensity was observed when cells had been precultured with the HDAC inhibitors.

Taken together, these results indicate that HDACs downregulate NFKB-dependent gene transcription downstream of NFKB DNA binding.

\section{Discussion}

HDAC inhibitors have been used in the treatment of various malignancies based on their ability to promote terminal differentiation and apoptosis in cancer cells. In addition, the anti-inflammatory potential of these compounds has also been demonstrated in animal models of autoimmune diseases such as rheumatoid arthritis and systemic lupus erythematosus $[4,7-10]$.

The beta cell destruction and insulin deficiency characterising type 1 diabetes mellitus is at least partially believed to be mediated by cytokines, such as IL- $1 \beta$ and IFN $\gamma$. Here we demonstrate that inhibition of HDACs by two different HDAC inhibitors, SAHA and TSA, each exhibited a protective effect against the detrimental effects of cytokines, preventing cytokine-mediated reduction in accumulated insulin secretion, inhibition of mitochondrial function and increase in iNOS production, NO formation and apoptosis. This was shown in a beta cell line (INS-1) and in primary rat islets. Similar results have been obtained using the novel HDAC inhibitor, ITF (data not shown. For information on ITF, see [19]).

TSA and SAHA are two structurally related reversible inhibitors of HDACs in vitro and in vivo. By binding to the zinc-containing pockets of HDAC, they inhibit the activity of class I and II HDACs [36]. Of the ten HDACs, HDAC $1-3,5,6$ and 8 are produced to various degrees in the pancreas [37], and as shown in this study, both SAHA and TSA are capable of inhibiting HDAC activity in insulinsecreting cells (see Fig. 1). Inhibition of HDAC results in increased acetylated nuclear histones [8], although global 

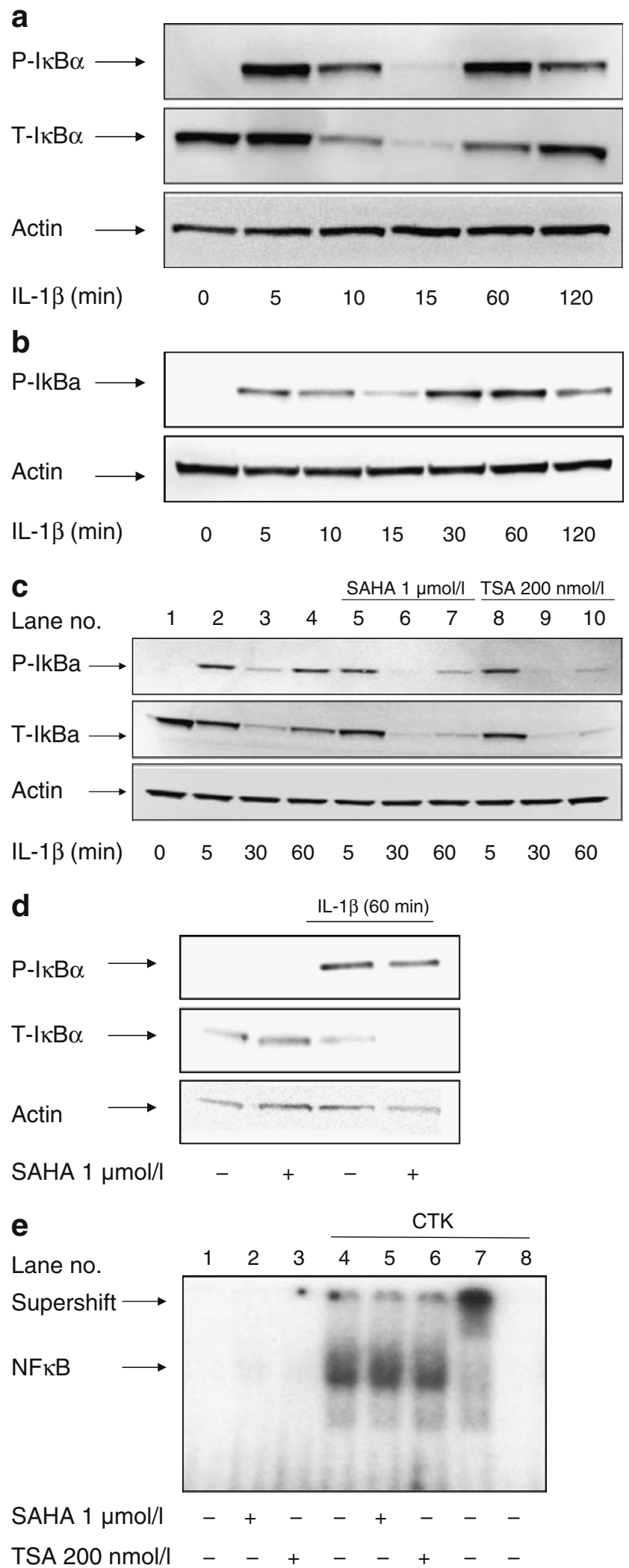

Fig. 5 Effects of HDAC inhibition on inhibitor protein kappa B alpha $(I \kappa B \alpha$.$) . a INS-1E cells were treated with \mathrm{IL}-1 \beta(160 \mathrm{pg} / \mathrm{ml})$ for various time points. Lysates were subjected to immunoblotting using antibodies towards phosphorylated $(P) \mathrm{I} \kappa \mathrm{B} \alpha$, total $(T) \mathrm{I} \kappa \mathrm{B} \alpha$ and actin. b Neonatal rat islets were exposed to IL-1 $\beta(150 \mathrm{pg} / \mathrm{ml})$ and lysates subjected to immunoblotting as described (for a). c INS-1E cells were pre-cultured with SAHA $(1 \mu \mathrm{mol} / \mathrm{l})$ or TSA $(200 \mathrm{nmol} / \mathrm{l})$ for $30 \mathrm{~min}$ followed by IL-1 $\beta(160 \mathrm{pg} / \mathrm{ml})$ exposure for various time points and analysed as described above $(n=4)$. d Neonatal rat islets were pre-cultured with SAHA $(1 \mu \mathrm{mol} / \mathrm{l})$ for $60 \mathrm{~min}$ followed by IL- $1 \beta$ $(150 \mathrm{pg} / \mathrm{ml})$ exposure for an additional $1 \mathrm{~h}$. Representative blots are shown for each experiment $(n=4)$. e EMSA was performed using nuclear extracts from INS-1E cells pre-cultured with SAHA $(1 \mu \mathrm{mol} / 1)$, TSA $(200 \mathrm{nmol} / \mathrm{l})$ or vehicle for $30 \mathrm{~min}$, followed by IL-1 $\beta 160 \mathrm{pg} / \mathrm{ml}$ and IFN $\gamma 5 \mathrm{ng} / \mathrm{ml}(C T K)$ for $1 \mathrm{~h}$. An NFkB-binding oligonucleotide was used as probe and super-shift performed using an anti p65 antibody (lane 7). Competition was performed using 1,000-fold excess of unlabelled oligonucleotide (lane 8)

analysis of gene expression following SAHA exposure in cancer cell lines estimated that a very low percentage (approximately 2\%) of the genome is regulated by HDAC inhibitors causing both up- and downregulation of genes [38]. SAHA has been used effectively in human primary cells and without overt toxicity in animal models and human trials $[8,32,39,40]$.

In this study we used islets from newborn and adult rats. One could argue that effects seen in islets isolated from neonatal rats might not be analogous to the outcome in adult islets, as gene expression and sensitivity to cytotoxicity are known to change during the postnatal maturation of islets [41]. However, as protection against apoptosis was observed in both types of islets, the HDAC inhibitors used by us seem equally potent in their ability to protect primary islets against the toxic effect of cytokines, regardless of maturational stage.

Although we generally observed similar positive effects of HDAC inhibition in cytokine-exposed cells, irrespective of cell source, minor toxicity on insulin secretion and apoptotic rate was observed in beta cell lines, especially with TSA. This discrepancy between tumour beta cell lines and primary rat islets may be explained by the fact that tumour cell lines such as INS-1 cells respond to HDAC inhibition similarly to other cancer cells, in which HDAC inhibition is known to induce cell death. This observation further substantiates the importance of using primary beta cells when investigating apoptotic signalling.

Nitric oxide is known to be toxic to beta cells and the prevention of cytokine-induced cell death by HDAC inhibition could at least partly be associated with a decrease in iNOS production and NO formation. The apparent paradox that HDAC inhibition prevents cytokine-induced iNOS production, but only partially inhibits NO-formation (Fig. 4c,e and f) may be explained by the difference in exposure time to cytokines ( $6 \mathrm{~h}$ versus 2 days for iNOS production and NO assay, respectively). Although the protective effect against 
cytokine-mediated NO formation was less pronounced in islets than in INS-1 cells, the effect on cytokine-induced apoptosis was more prominent in primary cells. As NO is known to cause cell death by necrosis and apoptosis [35], this may indicate that the proportion of cytokine-induced cell death by necrosis is greater in INS-1 cells than in primary rat islets. Another explanation may be that SAHA induced increased levels of thioredoxin proteins and activity, an induction seen in normal cells but not in transformed cells [32]. Thioredoxin is an active reactive oxygen species (ROS) scavenger and the ROS pathway has been implicated in impaired insulin secretion and cell death in beta cells [42, 43]. Beta cells seem to have inadequate defence mechanisms against oxidative stress, making them particularly vulnerable to this phenomenon compared with non-beta cell counterparts.

A common active form of NFKB is a heterodimer of $\mathrm{p} 65$ and p50. Through its activation domain, p65 has been shown to interact with co-activators [12] and more recent studies indicate that the phosphorylation status of p65 is a decisive factor for such interaction. Stimulus-induced phosphorylation of p65 at serine residue 276 determines whether it associates with co-activators or co-repressors, as phosphorylation facilitates CREB binding protein/p300 association, while affinity of HDAC-1 for $\mathrm{p} 65$ is decreased [44]. This phosphorylation precedes NFKB acetylation, leading to increased expression of NFKB-responsive genes [45]. We have previously shown that serine 276 does indeed play an important role in cytokine-stimulated NF KBmediated gene expression in beta cells [25] setting the stage for cytokine-induced NFKB acetylation.

Previous studies in other cell systems have suggested a link between TSA- and SAHA-mediated downregulation of proinflammatory gene expression and alterations in the NF $\kappa B$ signalling pathway. However, the underlying mechanisms seem to depend on the cell type investigated and include on the one hand an HDAC-inhibitor-mediated continual degradation of de novo synthesised $\mathrm{I} \kappa \mathrm{B} \alpha$ protein (possibly by prolonged activation of the upstream IкBkinase) causing prolonged presence and DNA-binding of $\mathrm{NF} \kappa \mathrm{B}$ in the nucleus and enhancing NFKB-dependent transactivation, or on the other hand a reduction in proteasomal degradation of I $\kappa \mathrm{B} \alpha$, preventing NF $\mathrm{KB}$ nuclear translocation and DNA binding [4, 8, 46-49].

The lack of reappearance of total-IKBa after HDAC inhibitor exposure in our study was associated with a decrease in $\mathrm{I} \kappa \mathrm{B} \alpha$ phosphorylation and no change in NFKB DNA binding activity after $1 \mathrm{~h}$ of stimulation, suggesting that HDAC influences NFKB-dependent gene expression down-stream of DNA binding in beta cells, probably by modulating the chromatin structure of NFkB-dependent genes, leading to increased $\mathrm{NF} \kappa \mathrm{B}$ transactivation, promoter activity and iNOS protein production, as has been demonstrated in cultured mesangial cells $[4,50]$.
While we observed a complete prevention of cytokineinduced decrease in accumulated insulin secretion when pretreating with $\mathrm{HDAC}$ inhibitors (see Fig. $2 b$ and c), no effect was seen on acute glucose-stimulated insulin-release after 6 or $20 \mathrm{~h}$ of cytokine-exposure (data not shown). These data show that HDAC inhibition protects against cytokine-induced reduction in accumulated insulin secretion by affecting pathways in the secretory response that are independent of the stimulus-secretion coupling of glucose. There are several possibilities of how changes in HDAC activity could affect these pathways, including posttranscriptional modifications of transcription factors or histone modifications induced in (pre)proinsulin gene expression or expression of genes involved in non-glucose-induced signaling of insulin secretion.

The present study provides evidence that changes in the balance of acetylation/deacetylation have a significant impact on the fate of cytokine-exposed beta cells. Our data prompt further analyses exploring the potential use of HDAC inhibitors to protect pancreatic islets from inflammatory attack in the development of type 1 diabetes, as well as in islet grafting.

Acknowledgements We thank A. S. Hillesø and H. Foght for excellent technical assistance. This work was financially supported by grants from the JDRF (grant no. 4-2002-457), and Danish Diabetes Association.

Duality of interest P. Mascagni is employed by and has received consultancy fees from a company that might benefit from the publication of data in this study.

\section{References}

1. Blanchard F, Chipoy C (2005) Histone deacetylase inhibitors: new drugs for the treatment of inflammatory diseases? Drug Discov Today 10:197-204

2. Eberharter A, Becker PB (2002) Histone acetylation: a switch between repressive and permissive chromatin. Second in review series on chromatin dynamics. EMBO Rep 3:224-229

3. Horn PJ, Peterson CL (2002) Molecular biology: chromatin higher order folding: wrapping up transcription. Science 297:1824-1827

4. Yu Z, Zhang W, Kone BC (2002) Histone deacetylases augment cytokine induction of the iNOS gene. J Am Soc Nephrol 13:2009-2017

5. Glaser KB, Staver MJ, Waring JF, Stender J, Ulrich RG, Davidsen SK (2003) Gene expression profiling of multiple histone deacetylase (HDAC) inhibitors: Defining a common gene set produced by HDAC inhibition in T24 and MDA carcinoma cell lines. Mol Cancer Ther 2:151-163

6. Gray SG, Qian CN, Furge K, Guo X, Teh BT (2004) Microarray profiling of the effects of histone deacetylase inhibitors on gene expression in cancer cell lines. Int J Oncol 24:773-795

7. Leoni F, Zaliani A, Bertolini G et al (2002) The antitumor histone deacetylase inhibitor suberoylanilide hydroxamic acid exhibits anti-inflammatory properties via suppression of cytokines. Proc Natl Acad Sci USA 99:2995-3000 
8. Mishra N, Reilly CM, Brown DR, Ruiz P, Gilkeson GS (2003) Histone deacetylase inhibitors modulate renal disease in the MRL1pr/lpr mouse. J Clin Invest 111:539-552

9. Nishida K, Komiyama T, Miyazawa S et al (2004) Histone deacetylase inhibitor suppression of autoantibody-mediated arthritis in mice via regulation of p16INK4a and p21(WAF1/Cip1) expression. Arthritis Rheum 50:3365-3376

10. Reilly CM, Mishra N, Miller JM et al (2004) Modulation of renal disease in MRL/lpr mice by suberoylanilide hydroxamic acid. J Immunol 173:4171-4178

11. Ortis F, Cardozo AK, Crispim D, Storling G, Mandrup-Poulsen T, Eizirik DL (2006) Cytokine-induced pro-apoptotic gene expression in insulin-producing cells is related to rapid, sustained and non-oscillatory NFKB activation. Mol Endocrinol 20:1867-1879

12. Chen LF, Greene WC (2003) Regulation of distinct biological activities of the NF-kappaB transcription factor complex by acetylation. J Mol Med 81:549-557

13. Arenzana-Seisdedos F, Turpin P, Rodriguez M et al (1997) Nuclear localization of I kappa B alpha promotes active transport of NF-kappa B from the nucleus to the cytoplasm. J Cell Sci 110:369-378

14. Gray SG, De Meyts P (2005) Role of histone and transcription factor acetylation in diabetes pathogenesis. Diabetes/Metab Res Rev 21:416-433

15. Eizirik DL, Mandrup-Poulsen T (2001) A choice of death-the signal-transduction of immune-mediated beta-cell apoptosis. Diabetologia 44:2115-2133

16. Giannoukakis N, Rudert WA, Trucco M, Robbins PD (2000) Protection of human islets from the effects of interleukin-1beta by adenoviral gene transfer of an Ikappa B repressor. J Biol Chem 275:36509-36513

17. Heimberg H, Heremans Y, Jobin $C$ et al (2001) Inhibition of cytokine-induced NF-kappaB activation by adenovirus-mediated expression of a NF-kappaB super-repressor prevents beta-cell apoptosis. Diabetes 50:2219-2224

18. Darville MI, Eizirik DL (1998) Regulation by cytokines of the inducible nitric oxide synthase promoter in insulin-producing cells. Diabetologia 41:1101-1108

19. Leoni F, Fossati G, Lewis EC et al (2005) The histone deacetylase inhibitor ITF2357 reduces production of pro-inflammatory cytokines in vitro and systemic inflammation in vivo. Mol Med 11:1-15

20. Asfari M, Janjic D, Meda P, Li G, Halban PA, Wollheim CB (1992) Establishment of 2-mercaptoethanol-dependent differentiated insulin-secreting cell lines. Endocrinology 130:167-178

21. Larsen CM, Wadt KA, Juhl LF et al (1998) Interleukin-1betainduced rat pancreatic islet nitric oxide synthesis requires both the p38 and extracellular signal-regulated kinase $1 / 2$ mitogen-activated protein kinases. J Biol Chem 273:15294-15300

22. Brunstedt J, Nielsen JH, Lernmark $\AA$, The Hagedorn Study Group (1984) Isolation of islets from mice and rats. In: Larner J, Pohl S (eds) Methods in diabetes research, Part C. Wiley, New York, pp 254-288

23. Eizirik DL, Welsh N, Hellerstrom C (1993) Predominance of stimulatory effects of interleukin-1 beta on isolated human pancreatic islets. J Clin Endocrinol Metab 76:399-403

24. Nielsen JH, Linde S, Welinder BS, Billestrup N, Madsen OD (1989) Growth hormone is a growth factor for the differentiated pancreatic beta-cell. Mol Endocrinol 3:165-173

25. Larsen L, Storling J, Darville M et al (2005) Extracellular signalregulated kinase is essential for interleukin-1-induced and nuclear factor kappa B-mediated gene expression in insulin-producing INS-1E cells. Diabetologia 48:2582-2590

26. Roenn SG, Hansen JA, Lindberg K, Karlsen AE, Billestrup N (2002) The effect of suppressor of cytokine signaling 3 on GH signaling in beta-cells. Mol Endocrinol 16:2124-2134
27. Green LC, Wagner DA, Glogowski J, Skipper PL, Wishnok JS, Tannenbaum SR (1982) Analysis of nitrate, nitrite, and [15N] nitrate in biological fluids. Anal Biochem 126:131-138

28. Kekow J, Ulrichs K, Müller-Ruchholtz W, Gross WL (1988) Measurement of rat insulin. Enzyme-linked immunosorbent assay with increased sensitivity, high accuracy, and greater practicability than established radioimmunoassay. Diabetes 37:321-326

29. Nielsen K, Karlsen AE, Deckert M et al (1999) Beta-cell maturation leads to in vitro sensitivity to cytotoxins. Diabetes 48:2324-2332

30. Mosmann T (1983) Rapid colorimetric assay for cellular growth and survival: application to proliferation and cytotoxicity assays. J Immunol Methods 65:55-63

31. Melnick A, Licht JD (2002) Histone deacetylases as therapeutic targets in hematologic malignancies. Curr Opin Hematol 9:322-332

32. Kelly WK, Marks PA (2005) Drug insight: Histone deacetylase inhibitors-Development of the new targeted anticancer agent suberoylanilide hydroxamic acid. Nat Clin Pract Oncol 2:150-157

33. Camelo S, Iglesias AH, Hwang D et al (2005) Transcriptional therapy with the histone deacetylase inhibitor trichostatin A ameliorates experimental autoimmune encephalomyelitis. J Neuroimmunol 164:10-21

34. Heitmeier MR, Scarim AL, Corbett JA (1997) Interferon-gamma increases the sensitivity of islets of Langerhans for inducible nitric-oxide synthase expression induced by interleukin 1. J Biol Chem 272:13697-13704

35. Saldeen J (2000) Cytokines induce both necrosis and apoptosis via a common Bcl-2-inhibitable pathway in rat insulin-producing cells. Endocrinology 141:2003-2010

36. Finnin MS, Donigian JR, Cohen A et al (1999) Structures of a histone deacetylase homologue bound to the TSA and SAHA inhibitors. Nature 401:188-193

37. de Ruijter AJ, Van Gennip AH, Caron HN, Kemp S, van Kuilenburg AB (2003) Histone deacetylases (HDACs): characterization of the classical HDAC family. Biochem J 370:737-749

38. van Lint C, Emiliani S, Verdin E (1996) The expression of a small fraction of cellular genes is changed in response to histone hyperacetylation. Gene Expr 5:245-253

39. Armeanu S, Pathil A, Venturelli S et al (2005) Apoptosis on hepatoma cells but not on primary hepatocytes by histone deacetylase inhibitors valproate and ITF2357. J Hepatol 42:210-217

40. Nervi C, Borello U, Fazi F, Buffa V, Pelicci PG, Cossu G (2001) Inhibition of histone deacetylase activity by trichostatin A modulates gene expression during mouse embryogenesis without apparent toxicity. Cancer Res 61:1247-1249

41. Ekblond A, Schou M, Buschard K (1995) Cytotoxicity towards neonatal versus adult $\mathrm{BB}$ rat pancreatic islet cells. Autoimmunity 20:93-98

42. Kawasaki E, Abiru N, Eguchi K (2004) Prevention of type 1 diabete: from the view point of beta cell damage. Diabetes Res Clin Pract 66:S27-S32

43. Minn AH, Pise-Masison CA, Radonovich M et al (2005) Gene expression profiling in INS-1 cells overexpressing thioredoxininteracting protein. Biochem Biophys Res Commun 336:770-778

44. Zhong H, May MJ, Jimi E, Ghosh S (2002) The phosphorylation status of nuclear NF-kappa B determines its association with CBP/ p300 or HDAC-1. Mol Cell 9:625-636

45. Chen LF, Williams SA, Mu Y et al (2005) NF-kB RelA phosphorylation regulates RelA acetylation. Mol Cell Biol 25:7966-7975

46. Chakravortty D, Koide N, Kato Y et al (2000) The inhibitory action of butyrate on lipopolysaccharide-induced nitric oxide production in RAW 264.7 murine macrophage cells. J Endotoxin Res 6:243-247

47. Place RF, Noonan EJ, Giardina C (2005) HDAC inhibition prevents NF-kappa B activation by suppressing proteasome activity: Down-regulation of proteasome subunit expression stabilizes I kappa B alpha. Biochem Pharmacol 70:394-406 
48. Yin L, Laevsky G, Giardina C (2001) Butyrate suppression of colonocyte NF-kappa B activation and cellular proteasome activity. J Biol Chem 276:44641-44646

49. Adam E, Quivy V, Bex F et al (2003) Potentiation of tumor necrosis factor-induced NF-kappa B activation by deacetylase inhibitors is associated with a delayed cytoplasmic reappearance of I kappa B alpha. Mol Cell Biol 23:6200-6209

50. Yu Z, Kone BC (2005) Targeted histone H4 acetylation via phosphoinositide 3-kinase- and p70s6-kinase-dependent pathways inhibits iNOS induction in mesangial cells. Am J Physiol Renal Physiol 290:F496-F502 